darius in Europe. In this country, Mr. E. A. Schwarz has bred in Alabama, Sphaeropthalma sanbornii Blake, in both sexes, from the cells of an Andrenid, Nomia sp., while Dr. C. V. Riley has bred Sphaerophthalma balteola Blake from the cells of an Anthidium sp. sent him from Florida.

The Ants comprising the families XXI Dorylidae, XXII Formicidae, XXIII Odontomachidae, XXIV PonEridae, and XXV Myrmicidae, will be treated in a separate paper.

Family $X X V 1$. Chrysididae. This family is represented in our fauna by eleven genera and seventy-seven species. It forms a connecting link, through the family Proctotrypidae, with the $\mathrm{HY}_{\mathrm{Y}}$ menoptera Terebrantia, and the species composing it are among the most brilliant colored of our wasps. Some of the species are said to be "inquilines" or "guest-flies," others true parasites, but I believe all are genuine parasites. Mocsary in his recent great work, "Monographia Chrysididarum orbis terrarum universi" has brought together, in a tabular form, all the records of the rearings of these insects and it will be only necessary for me here to mention the habits of some of our own species.

Benj. D. Walsh seems to be the only one in North America who has made a record of the rearing of a species in this family. In Amer. ent., vol. I (I868), p. I35, he records having bred Chrysis coerulans Fabr. var. bella Cr. from Eumenes fraterna Say.

In treating of the genus Trypoxylon, I have aiready stated having seen Chrysis verticalis Pattn. entering the burrows of Trypoxylon carinifrons Fox, and this species is undoubtedly parasitic on that wasp. In Florida, I have bred Chrysis coerulans Fabr. and $C$. perpulchra $\mathrm{Cr}$. from the cells of Pelopaeus cementarius Drury, while from those of Odynerus quadrisectus Say issued Chrysis densa $\mathrm{Cr}$.

I have now given a resume of the habits of the Aculeate Hymenoptera, arranging the families in what I conceive to be their natural sequence, and as the Chrysididae terminates the series, my address, already too long, comes to an end.

\title{
FURTHER NOTES ON COLEOPTERA FOUND WITH ANTS.
}

BY HENRY FREDERICK WICKHAM, IOWA CITY, IOWA.

These records are offered as a continuation of the series begun in the last volume of Psyche.* Most of them are new, either as to the beetle or its host and the few others relate chiefly to

\footnotetext{
* Page 321.
}

doubtful species and are given as additional evidence regarding the true state of affairs. The ants are identified by Mr. Theo. Pergande, whose authority is amply sufficient guaranty as to correctness. Most of the Staphylinidae are given on the word of Capt. Thos. L. 
Casey, and many of them have only lately been described by him; the few manuscript names are given as being a trifle better than none because it will be at least possible to ascertain the identity of the species recorded by reference to his cabinet. The Scydmaenidae were named by Dr. Brendel. My thanks are due to all these friends for aid in the very difficult groups which have to be investigated in this class of work.

Ptomaphagus parasitus Lec. I took several specimens at Iowa Lity in the nest of Formica subsericea Say. This ant supports a host of inquilines and parasites as the following record of species will show. All of those credited to it were taken from a single large nest on the same afternoon.

Scydmaenus rasus Lec. One specimen at Iowa City, with Lasius niger L. $\dagger$

Scydmaenus favitarsis Lec. With Formica subsericea, one specimen.

Eumicrus motschulskii Lec. ("Apparently a large specimen of this species and certainly not grossus"), one specimen with Lasius niger at Iowa City.

Adranes lecontei Brend. Found in the autumn, at Iowa City, in the nest of a Lasius which Mr. Pergande thinks may be a variety of $L$. minutus Em. In the spring, I take it with L. aphidicola Walsh.

Ceophyllus monilis Lec. Occurs at the same time and in the same nests as the preceding species.

$\dagger$ Mr. Pergande writes that this is the form heretofore considered identical with $L$. alienus.
Batrisus lineaticollis Aubé. Taken with Formica subsericea. Oniy two or three specimens obtained.

Atheta iowana Casey (in litt.) and $A$. terminata id., both occur with $F$. subsericea. Atheta limatula id. was taken at Iowa City with Lasius niger while $A$. exilissima id. was captured with Solenopsis debilis at Cañon City, Colo.

Lomechusa cava Lec. At Iowa City with Camponotus pictus Forel. Several specimens are often to be found in the same nest.

Myrmedonia calignosa Casey. With ants at Iowa City, April 20. No specimens of the host were saved.

Myrmecochara crinita Casey. This is the species which was most unfortunately referred to Gyrophaena in the first paper. I am intebted to $\mathrm{Mr}$. E. A. Schwarz for first calling attention to my error. Mr. Fauvel considers the insect as constituting a new genus but now that it has received a specific name it will be a matter of no great difficulty to keep track of it in the future.

Microdonia occipitalis Casey. With ants, at Walnut, Arizona, July $2 \mathrm{I}$. Two specimens.

Myrmobiota crassicornis Casey. At Iowa City with Lasius niger. Two specimens.

Heterothops fumigatus Lec. With Formica subsericea. It is more often to be found at large than in ants' nests.

Philonthus microphthalmus Horn. One specimen with $F$. subsericea. I once got another specimen with an ant 
(Aphaenogaster fulva) but usually take it at large.

Scopaeus brevipennis Casey (in litt.). This is the species recorded in the pre. vious paper, without a name. It occurs with Aphaenogaster fulva.

Oxytelus placusinus Lec., and $O$. suspectus Casey were taken with Formica subsericea. They probably make galleries of their own in the ant-hill rather than dwell in the run ways of the ants.

Atomaria mesomela Hbst.. "or one of the other 4-maculate species" (Brendel). This occurs at Iowa City with an Aphaenogaster, the identity of which cannot be determined with the limited material in hand. Several specimens were taken from one nest. This is probably not the customary habit of this species.

\section{TWO CAVE BEETLES NOT BEFORE RECORDED.}

BY H. GARMAN, LEXINGTON; KY.

Two small beetles have proved so constantly present in small caves in the vicinity of Lexington that it seems worth while to place them on record as cave insects. Both have pretty well developed eyes and may therefore live at times in ordinary situations, but they are perfectly at home in the deepest parts of caves and are at times very abundant there. In all my collecting in ordinary situations I have not seen either species out-of-doors, and am disposed to consider them true cave dwellers.

Choleva alsiosa, Horn. This is a small black beetle (one of the Silphidae) about $4.5 \mathrm{~mm}$. in length, described in 1885 by Dr. Horn from the Yukon River, Alaska. Is it possible that the low temperature prevailing in the caves has enabled this insect to persist here since glacial times? I have several hundred specimens, male and female, all taken in caves beyond the penetration of light.
Calodera cavicola, n. s. A small, reddish brown insect with very short wing covers and a slender elongated body. Head generally darker than the body, sometimes nearly black in alcoholic specimens. The middle of the abdominal somites also darker than elsewhere giving this division of the body an annulated appearance. Specimens taken from the caves and kept alive seem to me to become gradually darker in general color. It is one of the Staphilinidae.

Length 4.5-6.0 $\mathrm{mm}$. Greatest width about $1.0 \mathrm{~mm}$. Outline of head, seen from above, nearly circular, truncate behind, its length contained $I_{5}^{\frac{1}{6}}$ times in width, pubescent and obsoletely punctate above. Antennae when drawn back reaching nearly to posterior edge of prothorax, gradually enlarging from the base, finely pubescent, and with a ring of rather strong hairs on most of the segments. First to third segment cylindrical, the basal largest and longest of the three, the second and third nearly equal; fourth segment shortest, contracted 

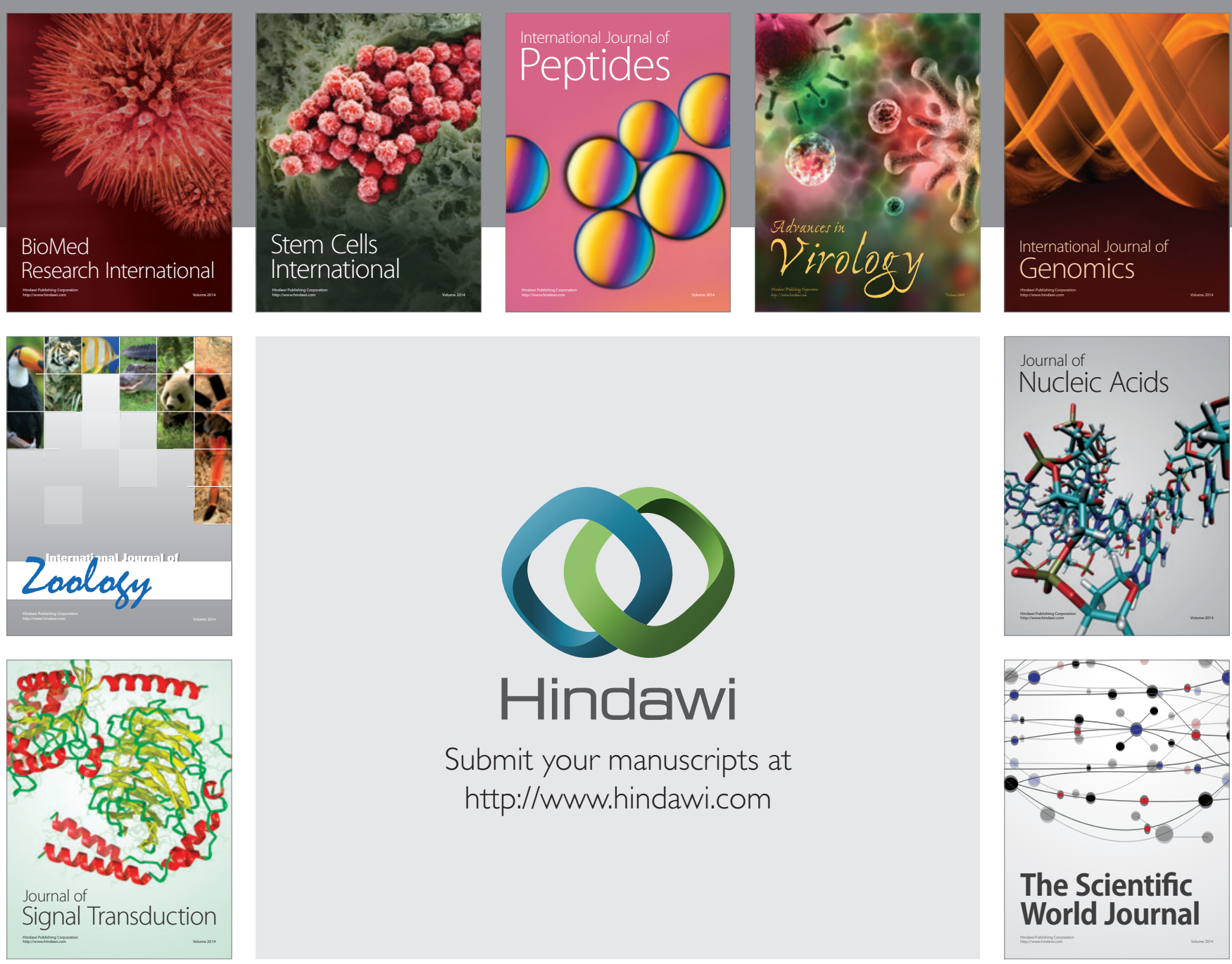

Submit your manuscripts at

http://www.hindawi.com
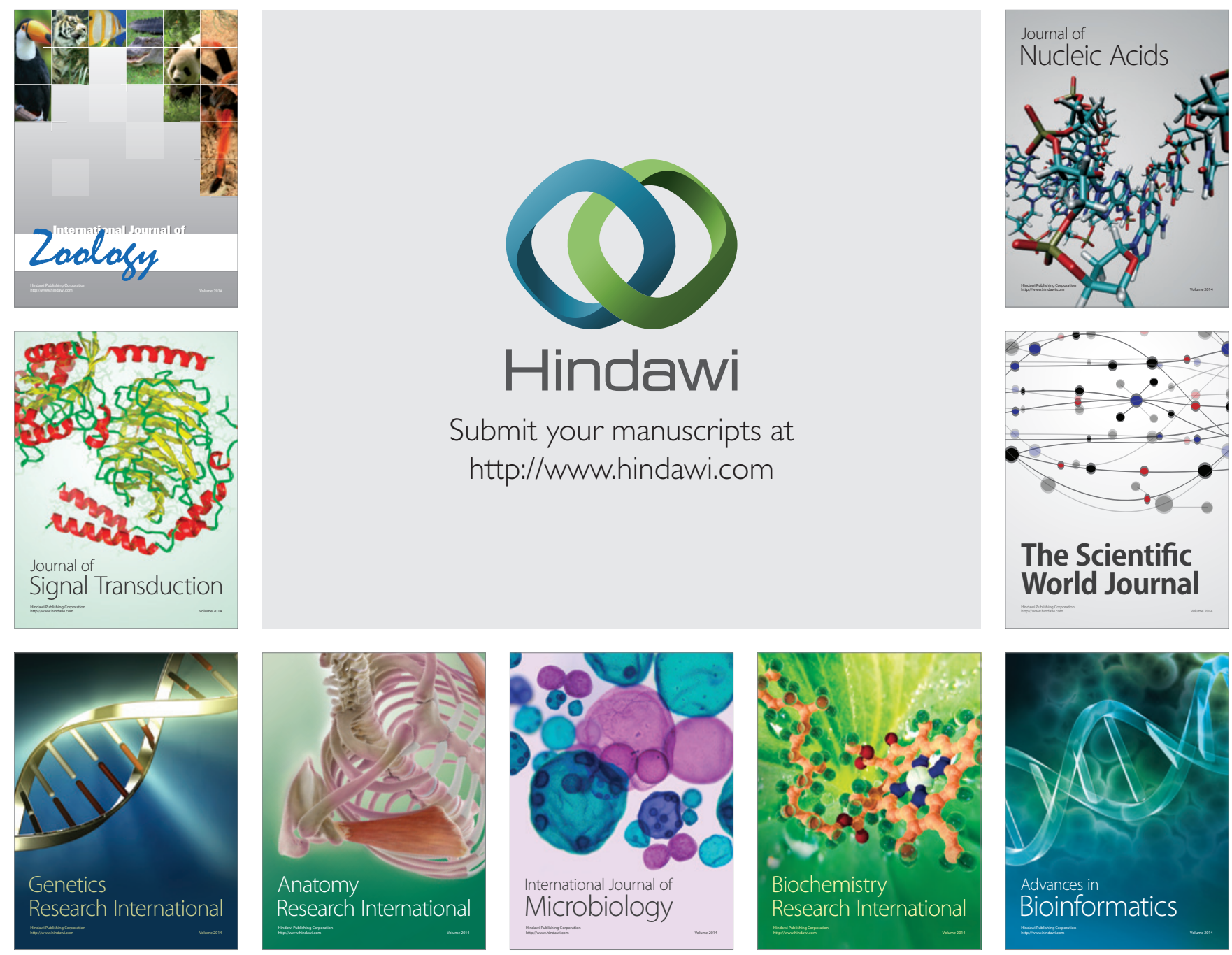

The Scientific World Journal
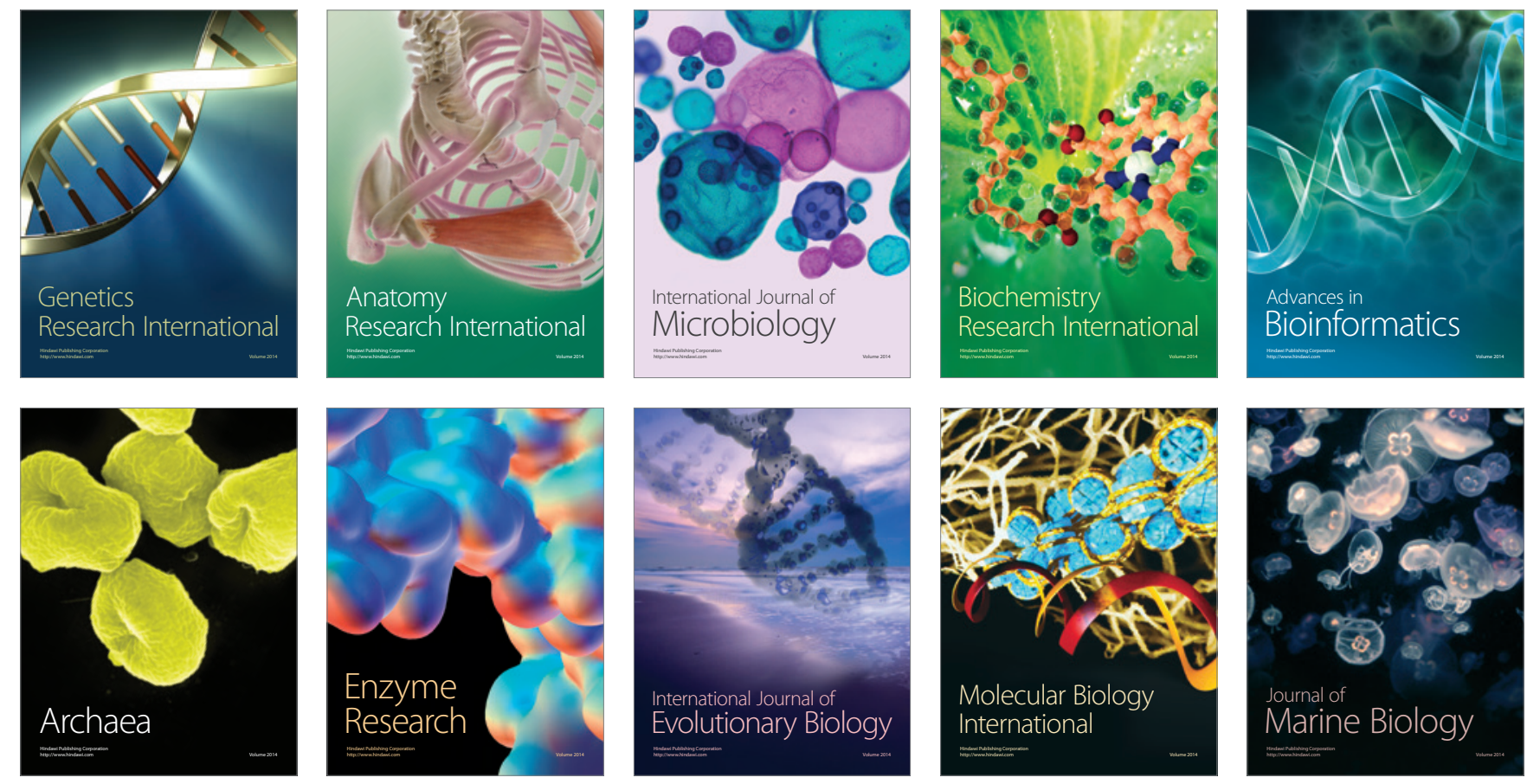